\title{
Value and Character Learning Through Playing Egrang: Qualitative Study at Tonaker Playground Ledokombo Jember Indonesia
}

\author{
Sa'dun Akbar \\ State University of Malang, Indonesia \\ sadun.akbar.fip@um.ac.id
}

\begin{abstract}
These research aims are describe: (1) character learning through playing Egrang; (2) learning impact of playing Egrang to character value; and (3) construct preposition of character learning through Playing Egrang. This study use qualitative approach. Data collected by observation, interview, and documentation, then analyzed by qualitative method. The research findings are character learning through playing Egrang operationalized by: the first (1) create learning situation which support learning character values by arrange physical, social, and psychological situation; (2) practice playing Egrang; (3) Egrang Play contest; and (4) series of Egrang game activities. The second, character values that emerged from playing Egrang and various activities that support Egrang game are: discipline, cooperative, confidence, caring for others, obedient, openness, and polite communication. The third, Egrang games can build discipline, cooperative, confidence, caring for others, and polite communications character. Recommended that use Egrang Plays to develop character values.
\end{abstract}

Keywords: Egrang plays, value and character education

\section{INTRODUCTION}

In the area of East Java Jember there is a village and district Ledokombo located not so far from the city of Jember. Many population of Ledokombo villages work outside the village even abroad as Indonesian Migrant Workers (TKI). Many parents are migrating abroad due to economic limitations. Because of many parents leave their villages to work abroad, so many children are left behind by parents, which means they are getting less attention from their parents. Many student of SD and SMP age are abandoned by their parents.

Departing from the concern of a Supo and Chichi (a husband and wife) then stands an NGO with the name Tanoker (which means a cocoon). The vision of the Tanoker learning community according to $\mathrm{Mr}$. Supo's statement is "to seek to bring together human beings from different cultures to unite, share and strengthen each other in a living space called Ledokombo. Making Ledokombo a "Culturally Friendly Cultural Area" and a meeting place for various backgrounds (groups, races, ethnicities, nations and cultural groups) to strengthen each other for peace, justice and prosperity. The purpose of the activities packed in the form of learning while studying mainly focus on the development of children's potential through the process of organizing with local cultural approach (Akbar, 1915) is very closely related to character education.

Children who are less careful and vulnerable to threats that damage their future are nurtured and developed by Tanoker potential. Coaching, mention Tanoker children is done in a playground (place of dolanan - in Javanese language) located in Ledokombo (ledok = place in the lower basin, ombo = area). Appear in this Tanoker Children's Playground looks beautiful, around it a lot of plants are quite thick so good to take shelter. In this park children play Egrang (a traditional game that is already rare). The following picture is between Tanoker Ledokombo playground.

In the garden above are the children of Tanoker play, with the coaching of a couple of husband and wife (Supo-Chichi) who with all their heart and energy to save the future of children who lack the attention of his parents. Initially this place is just a place to play children, but in the process of development Tanoker become a Community-based Culture and can be a vehicle for children's character building.

The Egrang game became one of the traditional local game types that is highly favored in Tanoker and sought for its preservation by Tanoker. The stage festivals that are held on an annual basis can also be a testament to the preservation of the traditional game. Based on preliminary studies that researchers do, through the game Egrang and various games and activities that accompany it turns out the game Egrang can be a game that can be utilized for children character building. This study aims to describe: (1) how character learning is done through the game of stilts; (2) the impact of the stage game in character development; and (3) establish a linkage proposition of the Egrang game with characters.

\section{METHODS}

This study use qualitative approach. Researchers strive to interpret the phenomenon of the game Egrang and a series of activities and games that accompany it in the context of character education. Data collected by observation, interview, and documentation, then analyzed by qualitative method. Observation techniques were conducted to collect data on the implementation of the Egrang game and various other accompanying activities and games, observing the characters that appear in the Tanoker community, and the educational and learning atmosphere that exist within the Tanoker community.

Interview techniques were used to collect data on the reasons why the Tanoker community was built, Tanoker's vision, and explore the character of children that could be presented through the learning community at Tanoker. Documentation techniques are used to uncover various activities within the Tanoker learning community and document the physical and social arrangements within the Tanoker Community and others. Data were analyzed qualitatively by cyclically through description, reduction, categorization, and reduction. 


\section{RESULT}

The Tanoker learning community was formed initially from concerns about the number of schoolaged children who received less attention from their parents because their parents worked as migrant workers who worked outside the village, out of town or even abroad. In the process of development the learning community is able to attract other children (even though their parents do not work outside Ledokombo Village) because of the huge benefits that can be gained from the learning community spearheaded by Supo and Chichi (a married couple) who vigorously convey energy, and materials to nurture the children of Tanoker while preserving local culture that contains many local wisdom.

The Tanoker children learn while playing at a Tanoker Playground located in Ledok Ombo, which looks a lot of shady plants, beautiful, and cool. The Tonaker kids learn a lot of things in this place through playing Egrang as the most dependable traditional game. Among the playground images are shown in the picture as follows (Figure 1).
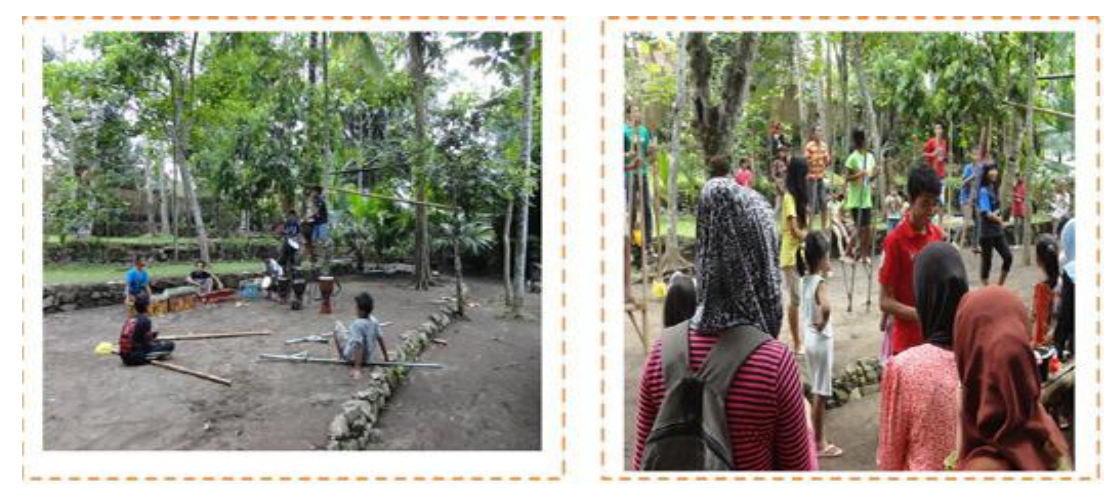

Figure 1

The Tanoker Community Playgrounds

The two images above are some of the Tanoker Community Playgrounds in Ledokombo. Tanoker playground looks Natural, the existing trees are grown naturally, but with a pretty good arrangement. Among the trees there is a poster of motivational words about character values. For example there are writings "Keep Hygiene", "please for those who smoke outside the Tanoker play area", "after reading put the book in its place", after playing music place the instrument in its place", "Welcome to Tanoker ", and others .

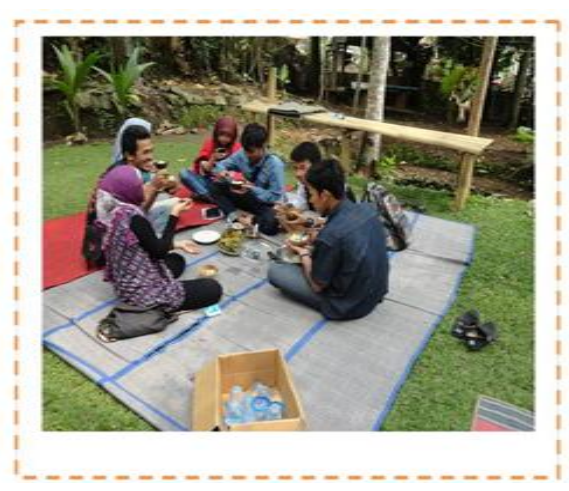

In terms of social arrangement, it appears that the social interaction between Tanoker (Pak Supo and Mrs. Chici) builder with Tanoker children looks familiar no distance. The atmosphere of kekekeluargaan, togetherness, and appreciation to each other and to the guests feels once so enter the atmosphere of life in the learning community. The visiting guests get a warm welcome even in simplicity.

Figure 2

Social Interaction in The Tanoker Community

The picture above (left) shows the Tanoker children having lunch together with a very simple menu but they can eat together. The picture (right) illustrates the direction of the coach being carried out by a coach with the Tanoker children on the sidelines they are playing. They appear relaxed sitting on mats but seriously pay attention to the coach when giving direction and advice.

The most favored Tanoker children's game is the Egrang game. Game Stilts are traditional games, using a piece of bamboo tool that at a certain height is given a footstool for the footstool as a pedestal. The 
stilts are shown below (left picture) and the children's picture playing on the Egrang appears on the right picture as follows (Figure 3).

Game Stretch can be done by playing: alone/single, in pairs, and in groups. They can perform the movements in anaktaktanya lift one foot above stilts, running, dancing even on stilts by following the rhythm of the song Disco. When playing in groups all the movements are performed simultaneously and compact. Even when the group is held by the group, the participants can demonstrate their dancing skills on stilts with movements that seem very agile and able to maintain balance. This festival is able to suck a very large audience both from within and from abroad.

Achieving the ability to play Egrang well requires adequate training. Tonaker's children spent much of their time in this Tanoker Playground. In the process of training they can learn each other, help each other, tolon-help, eat together, serve the guests who are present in different locations, keep the Garden clean, maintain the Garden, play music to accompany children playing Egrang. In another corner there are groups learning to play music, learning work skills, even studying in groups doing tasks from school with the help of tutors. The atmosphere of learning while, playing, learning by doing, learning to add insight from the guests who used as a source of learning, feel 'urip together' in an atmosphere of simplicity of mutual help and cooperation, and doing real jobs by applying the skills to play in the game Egrang, jobs taking care of the park, playing music accompanying the Egrang game, serving guests, and serving each other amongst the Tonaker's children.
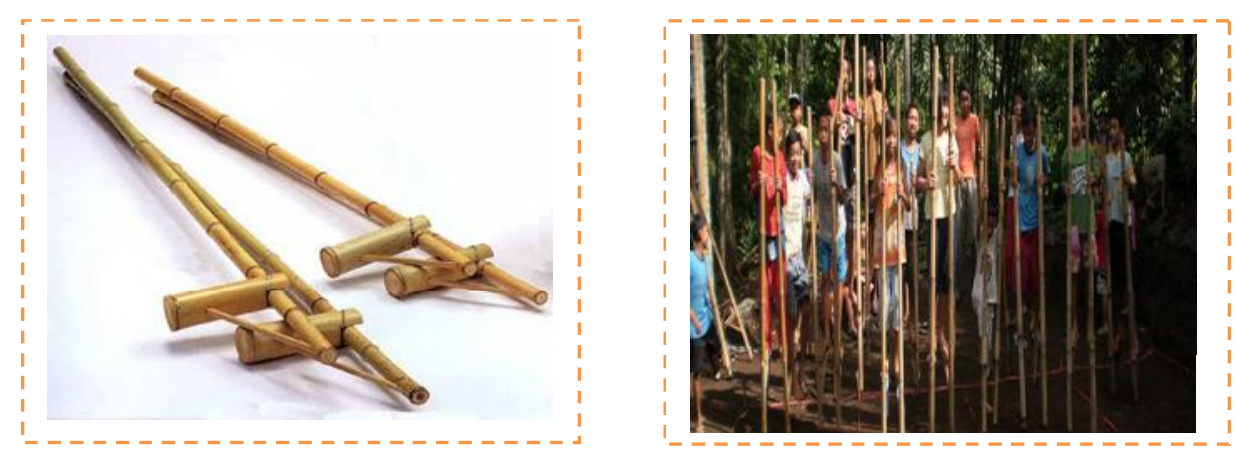

Figure 3

The children's Playing on the Egrang

From a series of activities in the Egrang game, based on the observations and interviews that the researcher does, it looks very much: the character of togetherness, cooperation, obedience to the rules, caring to others, polite communication, and even confident characters can be presented through the Egrang game. The substantive theory that can be constructed from the game and play Stage and the accompanying series of activities such as: eating together, playing music, serving the guests, taking care of the gardens of playgrounds, etc. is that "the game of Egrang can bring value and character: cooperation and togetherness, discipline, obedience, caring, openness, and confidence.

\section{DISCUSSION}

Learning situations created within the Tanoker community are done by physical arrangement by natural, clean, beautiful garden arrangement with positively motivational posters that invite good character; as well as the stretching of social life without distance between mentor and children, social life that helps each other and appreciates able to create a conducive psychological situation for learning.

In phenomenology theory it is stated that a person lives in a living space or is in a field. In the living space there is a observed phenomenon and a living phenomenon. Observed phenomenon is the arrangement of the physical situation such as spatial arrangement, arrangement of parks, well-groomed parks, a variety of motive posters for good character. In addition, the observed phenomenon is the arrangement of social life such as the interaction of fellow children who play, the children with the supervisor, interaction with the guests, the interaction when eating together and others. From the observed phenomena arises the phenomenon that lived or appreciation of the physical and social situation. Well, from the appreciation of the physical and social order that will build the behavior (character) of a person. It is this conducive educational and learning situation that nurtures the growth of good character.

Education is essentially "dialogue" of dialogue between learners (let's say Tanoker children for example) with: posters, natural, beautiful, clean and beautiful gardens; dialogue between learners and the performance of their coaches, with the behavior of the people in the learning community, the dialogue between learners and the achievements of their fellow learners, amongst the learners (the children of Tanoker) with the guests present from various community colleges in Tanoker, dialogue with foreign tourists coming from other countries, dialogue with competitors in the Egrang competition while competing in the Egrang festivals, and others able to build the good character of the Tanoker children. 
Education need to be a conducive atmosphere of learning atmosphere. The importance of this atmosphere is analogous to the growth of a plant. As it is written in the Qur'an that "The fertile soil of its plants will flourish with the permission of Allah, and the arid land of its crops will grow miserably (QS: AlA'raf 58).

When the children play Stage, the result of interviews with the Egrang players, they are in a higher position than others who do not play Egrang, or are in a higher position above the audience of the game Egrang. When it is in that high position present themselves (players) self-confidence, so that confidence can be dipupun through playing Egrang. Stretching in groups requires discipline and cohesiveness in performing certain movements in team play situations that are trained to play in a compact and high-level discipline. So, the attitude of discipline and compact can also be presented through playing Egrang.

Playing Stilts requires the support of other activities such as eating together during breaks, working together to take care of the Playground, serving the guests who attended the Playground, and others. So a proposition can be constructed that the series of activities in the game of Egrang can develop the character of cooperation and togetherness, help, help, and polite communication.

With the many guests from universities such as students who are PPL, lecturers who perform community service, Foreign Tourists who visit the Tanoker Playground, where they are willing and used as a learning resource then Tanoker children get a wider insight. Thus, the various activities of the Egrang game supporters can present the character of openness. Well this openness is very potential to make someone more advanced and growing rapidly.

Learning by doing, implemented in the learning community of Tanoker learning that utilizes the real life in the natural environment of Ledokombo and involves local community support, learning-work-art, actually applying the principles of integrated learning, in fact, in line with the philosophy of "nature developed into teachers" as revealed by Mohammad Syafei, a Kayutaman education figure (Faizah, 2010) that the universe is a master-related teacher of spiritual intelligence and filled with emotional social intelligence that fosters hardworking, unyielding, confident, aesthetic, creative and sensitive characters as a divine servant (Faizah, 2010). By playing elementary school children can be accurate, uphold honesty, obedience to the rules, so the game is seen as a concrete mental and moral building (Faizah, 2008).

Practice of learning conducted at Tonaker Ledokombo applying the principle of development of insight, mentality mentoring that prioritize taste, intention, art, and sport in line with Lickona character education principles that involve "moral knowing, moral feeling, and moral action", as well as the principles of character education Ki Hajar Dewantoro namely "ngerti, ngroso, and nglakoni", also the practice of character education applied Abdullah Gymnastiar with the focus of balance "think, dhikir - remember God and endeavor".
The development of insights from various speakers present at Tonaker can sharpen the intelligence of thought, by serving each other and doing the work in the game park means happening is an initiative that can also trigger the feeling, with the practice of playing music as a companion game Egrang distu happen though art, and by playing Egrang itself can also be seen as a sport. The result of Akbar's (2012, 2013) study on the Implementation of Triprakoro Learning Model which incorporates the principles of ngerti, ngroso, and nglakoni can develop compliance stance on regulations and cooperation.

The results of research on integrated learning is very effective to achieve targeted learning objectives and rich with impact accompanist such as learners motivated, active, happy, healthy, and able to present the presence of positive attitudes. Akbar (2003) states that learning models of KDP SD Integrated is very Effective able to achieve the targeted learning objectives.

Akbar $(2006,2008)$ in his research on integrated thematic learning found that the implementation of integrated thematic learning models in addition to being highly effective in achieving targeted learning objectives also enabled students, made students creative, and able to develop personal skills-such as self-awareness, collaborate, and collaborate, theoretical academic proficiency skills, and vocational skills in the form of practical skills related to doing the work.

The choice on Stilts as an almost extinct traditional game, which in the game contains the local wisdom values of the archipelago that is contextual to the life of the local community. The principles of developing and implementing the strengthening of character education in Ledok Ombo are in line with the principle of prioritizing universal values-such as mutual cooperation, cooperation and togetherness, caring, polite communication, and openness; holisticwhich involves sports, thought, aesthetics, complete, participatory, public-involving, and responsive to local wisdom (PASKA, Kemdikbud 2017).

The choice on Stilts as an almost extinct traditional game, which in the game contains the local wisdom values of the archipelago that is the contextual to the life of the local community. The principles of developing and implementing the strengthening of character education in Ledok Ombo are in line with the principles of prioritizing universal values-such as mutual cooperation, cooperation and togetherness, caring, polity communication, and openness; holisticwhich involves sports, thought, aesthetics, complete, participatory, public-involving, and responsive to local wisdom (PASKA, Kemdikbud 2017).

\section{CONCLUSION}

Based on research finding and discussion above concluded that value and character learning through playing Egrang operatonalized by: the first: (1) create learning situation which support learning character values by arrange physical, social, and psychological situation; (2) practice playing Egrang; (3) Egrang Play contest, and (4) series of Egrang game activities. 
The second, character values that emerged from playing Egrang and various escort activities are: discipline, cooperative, confidence, caring for others, compliance, openness, and polite communications. The third, Egrang games can build discipline, cooperative, confidence, caring for others, and polite communications character. Recommended that use Egrang Plays to develop character.

\section{REFERENCES}

[1] Akbar, S., and Margono, N.S. 2003. Development of Integrated Models for KDP SD. Research Report SEQIP Project. Jakarta: Directorate of Kindergarten Elementary School.

[2] Akbar, S., Sutama, W. I., and Pujianto. 2006. Development of Thematic Learning for Primary and Grade Elementary Schools. Research Report. Malang: Lemlit State University of Malang.

[3] Akbar, S. 2011. The Revitalization of Character Education at Elementary School, Inauguration of Professor's Speech. Malang: State University of Malang.

[4] Akbar, S., Arafiq, Samawi A., and Hidayah, L. 2015. Best Practice of Character Education. Malang: UM Press.

[5] Akbar, S. 2013. Triprakoro Model for Development of Compliance Value. Journal of Educational Science, 19(1).

[6] Akbar, S. 2012. Implementation of Triprakoro Model for Cooperative Value Learning. IPS Research and Education Journal.

[7] Akbar, S. 2008. The Application of Thematic Learning to Improve the Quality of Learning Theme of the Environment in Class 3 SDN Tanjungrejo 3 Malang. Educational Science Journal, 35(2).

[8] Dewantoro, K. H. 1962. Part I: Education. Yogyakarta: Majlis Luhur Taman Siswa.

[9] Faizah, D. U. 2008. Learning Beauty in Perspective Pedagogy: Meaning of Traveling in Kindergarten and Primary Elementary Class, Jakarta: Publisher Cindy Abadi.

[10] Faizah, D. U. 2010. Active Directions: An Art of Creativity and the Noble Berakhlaq - The Compilation of Mohammad Syafei. Solo: Publisher of Tiga Serangkai Pusat Mandiri.

[11] Lickona, T. 1992. Educating for Character. New York: Bantam Book.

[12] PASKA, Secretariat General of Education and Culture. 2017. Concepts and Guidelines for Strengthening Character Education. Jakarta: Secretariat General of Ministries of Culture and Tourism (Kemdikbud). 